\title{
Lithium and Pregnancy-II, Hazards to Women Given Lithium during Pregnancy and Delivery
}

\author{
M. SCHOU, A. AMDISEN, O. R. STEENSTRUP
}

British Medical fournal, 1973, 2, 137-138

between 8 a.m. and 3 p.m. on the following day by the procedure described by Thomsen and Schou (1968).

\section{Summary}

The renal lithium clearance of a manic-depressive woman rose when she became pregnant and fell to the prepregnancy level when she gave birth. The lithium clearances of four healthy women were higher during pregnancy than after delivery. This emphasizes the need for frequent determinations of the serum lithium concentration and appropriate dosage adjustments during pregnancy and delivery.

\section{Introduction}

Lithium treatment during pregnancy and delivery usually does not expose the woman to extra risk. There are, however, cases where women who were previously well adjusted as regards lithium dosage and serum lithium concentration developed lithium intoxication at the time of delivery.

One such case was reported by Wilbanks et al. (1970) and Woody et al. (1971), another by Vacaflor et al. (1970) and Aoki and Ruedy (1971). Owing to development of ankle oedema these patients were placed on a low salt diet and given diuretics. At the time of delivery serum lithium rose to values of 4-5 mmol/1. and the patients developed clinical signs of lithium intoxication. Weinstein and Goldfield (1970), in commenting on these cases, emphasize the danger involved in exposing lithium-treated patients to salt-depleting procedures. It is, however, noteworthy that the intoxications did not occur until the time of delivery even though the women had been on low salt diet and diuretics for several weeks. An explanation of this might be that pregnancy and delivery affect the renal lithium clearance differently. The creatinine clearance increases during pregnancy and falls abruptly to normal values around the time of delivery. Since the lithium clearance under most circumstances is about a fifth of the creatinine clearance, it might undergo similar changes in relation to pregnancy and delivery.

\section{Procedure}

Four somatically and mentally healthy women, who attended the gynaecology and obstetrics outpatient clinic for routine examinations, agreed to have their renal lithium clearance determined during the latter part of the pregnancy and again after delivery. A small test dose of lithium carbonate $(600 \mathrm{mg}$, corresponding to 16.2 millimoles of lithium ion) was administered in the evening, and the lithium clearance was determined

\footnotetext{
Psychopharmacology Research Unit, Aarhus University Institute of Psychiatry, 8240 Risskov, Denmark

M. SCHOU, M.D., Reserrch Director, Professor of Biological Psychiatry A. AMDISEN, M.D., Associate Research Director

Department of Gynaecology and Obstetrics, Aarhus University, Denmark

O. R. STEENSTRUP, M.D., Associate Clinical Professor
}

\section{Results}

The lithium clearance of the four women 1-3 months before and 6-7 weeks after delivery is shown in the table. The mean lithium clearance fell from $29 \mathrm{ml} / \mathrm{min}$ before delivery to $15 \mathrm{ml} / \mathrm{min}$ after; this difference is statistically significant.

Renal Lithium Clearances for Four Healthy Women 1-3 Months before and 6-7 Weeks after Delivery

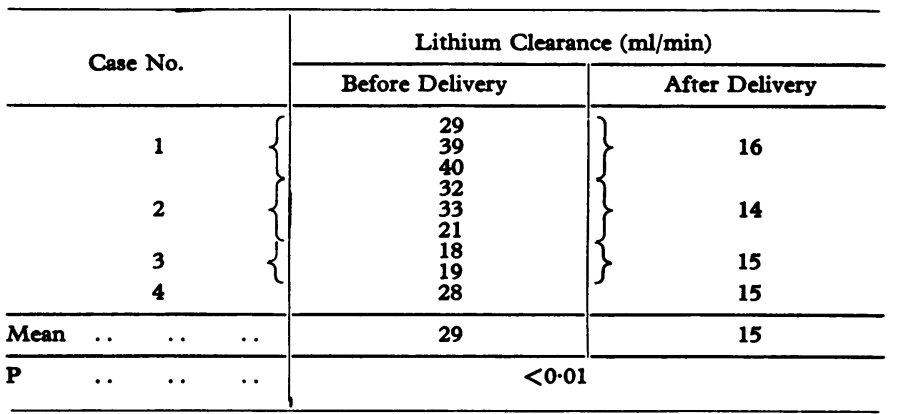

No data are available on the lithium clearances of the women from the time before they became pregnant, but we have observations on a manic-depressive woman. She was on lithium maintenance treatment before she became pregnant. At that time her renal lithium clearance was about $30 \mathrm{ml} / \mathrm{min}$, calculated on the basis of the lithium dosage and the serum lithium concentration (Schou et al., 1970). She became pregnant and continued lithium treatment with unaltered dosage. Her serum lithium level fell gradually, and direct determination of her lithium clearance in the manner described above showed a value of $48 \mathrm{ml} / \mathrm{min}$. The lithium dosage was then raised so that a serum lithium level of $1.0 \mathrm{mmol} / \mathrm{l}$. was obtained. Within a few days after delivery the patient experienced slight intoxication symptoms, and serum lithium had now risen to $1.5 \mathrm{mmol} / \mathrm{l}$. The lithium dosage was reduced, and when steady-state conditions had been achieved the renal lithium clearance was again calculated to be about $30 \mathrm{ml} / \mathrm{min}$.

\section{Discussion}

When the renal lithium clearance rises during pregnancy the serum lithium concentration falls, and the patient is exposed to risk of manic or depressive relapse. When at the time of delivery the lithium clearance falls to prepregnancy values the serum lithium concentration rises, and the patient is exposed to risk of lithium intoxication. This risk is higher if the patient is on a low salt diet or treated with diuretics. It is therefore important that the serum level is determined at not too long intervals during the pregnancy and particularly often during the days before and after delivery, so that appropriate dosage adjustments can be made. In cases where the lithium dosage has been raised during pregnancy it should be lowered at the time of the first contraction. Co-operation between the patient's psychiatrist and obstetrician is important. 


\section{References}

Aoki, F. Y., and Ruedy, J. R. (1971). Canadian Medical Association fournal, $106,112$.

Schou, M., Baastrup, P. C., Grof, P., Weis, P., and Angst, J. (1970). British fournal of Psychiatry, 116, 615 .

Thomsen, K., and Shou, M. (1968). American fournal of Physiology, 215, 823.
Vacaflor, L., Lehmann, H. E., and Ban, T. A. (1970). fournal of Clinical

Pharmacology, 10, 387 .
Weinstein, M. R., and Goldfield, M. D. (1970). Fournal of the American Medical Association, 214, 1325.

Wilbanks, G. D., Bressler, B., Peete, C. H., Cherny, W. B., and London,

W. L. (1970). Fournal of the American Medical Association, 213, 865 .

Woody, J. N., London, W. L., and Wilbanks, G. D. (1971). Pediatrics, 47, 94.

\title{
Lithium and Pregnancy-III, Lithium Ingestion by Children Breast-fed by Women on Lithium Treatment
}

\author{
M. SCHOU, A. AMDISEN
}

British Medical fournal, 1973, 2, 138

\section{Summary}

Children breast-fed by women on lithium treatment ingested lithium with the milk. Their serum lithium concentration was one-third to one-half the concentration in the nursing women's serum. Bottle-feeding should be considered for children of women on lithium treatment.

\section{Introduction}

Lithium passes from the blood into the milk, and children breast-fed by women on lithium treatment therefore ingest a certain amount of the drug. We have studied the quantities involved and the serum lithium concentrations produced in the infants.

\section{Procedure}

Some of our data are derived from the literature, some were reported to the Scandinavian Register of Lithium Babies, and some we obtained ourselves. The lithium concentration in milk was determined with a modification of the flame photometric method used for determining lithium in blood serum (Amdisen, 1967).

\section{Results}

The lithium concentration in milk was about half the lithium concentration in the nursing women's blood serum (see table). We have analyzed milk samples drawn at various times during

Psychopharmacology Research Unit, Aarhus University Institute of Psychiatry, 8240 Risskov, Denmark

M. SCHOU, M.D., Research Director, Professor of Biological Psychiatry A. AMDISEN, M.D., Associate Research Director 